Original Article

\title{
Molecular detection and prevalence of Rotavirus with acute gastroenteritis among the children of rural and urban areas
}

\author{
Detecção molecular e prevalência de rotavírus com gastroenterite aguda entre as \\ crianças de áreas rurais e urbanas
}

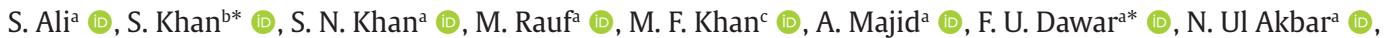 \\ R. Ullah' (D) A. Barie (D) and M. Y. Khanf (D) \\ aKohat University of Science \& Technology Kohat, Department of Zoology, Khyber Pakhtunkhwa, Pakistan \\ bUniversity of Peshawar, Department of Zoology, Khyber Pakhtunkhwa, Pakistan \\ 'University of Hazara Dhodial, Department of Zoology, Mansehra, Khyber Pakhtunkhwa, Pakistan \\ dCollege of Pharmacy, Department of Pharmacognosy, King Saud University Riyadh, Riyadh, Saudi Arabia \\ eKing Saud University Riyadh, College of Pharmacy, Department of Pharmaceutical Chemistry, Riyadh, Saudi Arabia \\ fLancaster University, Lancaster Environmental Centre, Lancaster, United Kingdon
}

\begin{abstract}
Rotavirus is the main infective agent of acute gastroenteritis (AGE) in children under the age of five years and causing significant morbidity as well as mortality throughout the world. The study was carried out to detect the prevalence rate, genotypes strain and risk factors of Rotavirus among the children of rural and urban areas of district Bannu Khyber Pakhtunkhwa Pakistan. A total of 180 stool samples were collected from children under the age of 5 years from two major hospitals of Bannu from January to December (2015). The samples were analyzed by Reverse-transcriptase Polymerase Chain Reaction (RT-PCR) for the detection of Rotavirus, positive samples were further processed for genotyping ( $G$ and $P$ type) through specific PCR. Of the total, 41 (23\%) samples were positive for Rotavirus. The most prevalent G genotypes found were: G3, G8, G9 (each 29\%), followed by G10 (15\%), and G11 (10\%). Whereas the prevalent P genotypes were: P-8 (25\%), P-4 and P-10 (each 20\%), P-9 (15\%), followed by P-6 and P-11 (each 10\%). Moreover, Rotavirus infection was more prevalent in summer (23.73\%) and winter (22.7\%) than spring (20\%) and autumn (21.4\%). Rotavirus infection exhibited high frequency in June (14\%), October (8\%) and November (6\%). It is concluded that Rotavirus is more prevalent in children and various genotypes (G and P) of Rotavirus are present in the study area. Lack of studies, awareness and rarer testing of Rotavirus are the principal reasons of virus prevalence in district Bannu, Pakistan.
\end{abstract}

Keywords: Rotavirus, genotypes G\&P, acute gastroentritis, risk factors, prevalance.

\section{Resumo}

O rotavírus é o principal agente infeccioso da gastroenterite aguda (AGE) em crianças menores de 5 anos e causa de morbidade e mortalidade significativas em todo o mundo. $O$ estudo foi realizado para detectar a taxa de prevalência, cepa de genótipos e fatores de risco de rotavírus entre as crianças de áreas rurais e urbanas do distrito de Bannu Khyber Pakhtunkhwa, Paquistão. Um total de 180 amostras de fezes foi coletada de crianças menores de 5 anos de dois grandes hospitais de Bannu de janeiro a dezembro (2015). As amostras foram analisadas por reação em cadeia da polimerase transcriptase reversa (RT-PCR) para deteç̧ão de rotavírus; as amostras positivas foram posteriormente processadas para genotipagem (tipo G e P) através de PCR específica. Do total, 41 (23\%) amostras foram positivas para rotavírus. Os genótipos $\mathrm{G}$ mais prevalentes encontrados foram: G3, G8, G9 (cada 29\%), seguidos de G10 (15\%) e G11 (10\%). Considerando que os genótipos P prevalentes foram: P-8 (25\%), P-4 e P-10 (cada 20\%), P-9 (15\%), seguido por P-6 e P-11 (cada 10\%). Além disso, a infecção por rotavírus foi mais prevalente no verão $(23,73 \%)$ e inverno $(22,7 \%)$ do que na primavera (20\%) e no outono (21,4\%). A infecção por rotavírus apresentou alta frequência em junho (14\%), outubro (8\%) e novembro (6\%). Conclui-se que o rotavírus é mais prevalente em crianças e vários genótipos $(\mathrm{G}$ e P) do rotavírus estão presentes na área de estudo. A falta de estudos, conhecimento e testes mais raros de rotavírus são as principais razões da prevalência do vírus no distrito de Bannu, Paquistão.

Palavras-chave: Rotavírus, genótipos G\&P, gastroentrite aguda, fatores de risco, prevalência.

*e-mail: sanaullahkhan@uop.edu.com; farmandawar@kust.edu.pk

Received: October 7, 2020 - Accepted: April 19, 2021 


\section{Introduction}

Acute gastroenteritis (AGE) is a community health problem that causes morbidity and mortality in children throughout the world, and mostly in developing countries. Rotavirus is one of the most important causes of AGE and in several countries, the infection burden and epidemiology are unknown (Al-Badani et al., 2014). Each year, almost 215,000 children die due to Rotavirus infection, of which up to $90 \%$ of deaths occur in low-income countries (Tate et al., 2016). The infection remains a foremost medical problem even in the developed countries, and about $80 \%$ of young ones experienced AGE in their first 3 years, the maximum rates of infection occurring during the $2^{\text {nd }}$ year. In the most current analysis, Rotavirus was responsible for approximately 128,500 deaths among children less than 5 years throughout the world (Martinez-Gutierrez et al., 2019).

Rotavirus is an dsRNA virus of the family Reoviridae, classified into seven groups (A-G) based on its genetic and antigenic characteristics. Rotavirus- $A$ is the most imperative pathogen that provokes infection mostly in children (Phan et al., 2007). The virus particle is a three-layered coated icosahedral particle, consists of two outer shell proteins i.e., VP4 (represent P genotypes) and VP7 (represents G-genotypes), one middle shell protein (VP6) and (VP2) is the innermost protein. Based on VP4 and VP7 variants, Rotavirus A is classified into $27 \mathrm{G}$ - and $35 \mathrm{P}$ - genotypes. The most significant Rotavirus types that commonly causes AGE are G2P-4, G4P-8, G1P-8, G3P-8, and G9P-8 (Matthijnssens et al., 2008).

The virus genotypes emerged due to mutations, the transmission of viruses from animal to human and the conduction of new animal strains resulting in the introduction of new antigenic variants (Martella et al., 2010). Identification of new variants of Rotavirus is measured through the distribution of important elements of epidemiological surveys, vaccine administration, prevalence studies of genotype, disease distribution, and efficacy program for monitoring. Studies have pointed out the impacts of constant surveillance of flowing Rotavirus strain in organize to sustain adequate immunity of the community. Unfortunately, the main causes and risk factors are not determined due to the lack of proper surveillance programs for the identification of Rotavirus strain and diagnostic facilities in Pakistan (Alam et al., 2013). Rotavirus infection occurs throughout the year globally but in Pakistan seasonality of Rotavirus causing AGE has never been determined (Kawai et al., 2012). While the country's health Ministry has started a hospital-based monitoring system to ELISA tests for the fecal specimens from the young one offered by AGE (Habib et al., 2014).

Presently two specific vaccines are extensively used against Rotavirus worldwide namely RotaTeq (Merck USA), and Rotarix (GlaxoSmithKline USA). In 2009, WHO suggested that the vaccine of Rotavirus should be incorporated in all national immunization programs (EPI). The extensive decrease in AGE correlated with hospitalization and mortality in those countries that have incorporated Rotavirus vaccines (Kilgore et al., 2013). In Pakistan, AGE is supposed to be the major cause of infant deaths (Qazi et al., 2009). However, a higher percentage(57 \& 63), of Rotavirus AGE infections was reported from Karachi and Faisalabad (Iftikhar et al., 2012). The high prevalence of Rotavirus AGE infections and genotypes was also reported from Rawalpindi and Islamabad, Pakistan (Sadiq et al., 2019). Very limited data is available from Pakistan related to Rotavirus with AGE and as a whole thoroughly collected information of AGE from different regions of the country is scarce (Alam et al., 2013). This study is therefore, designed to investigate the distribution of Rotavirus genotypes and their relationship with AGE in children under age five years of rural and urban areas of Pakistan.

\section{Materials and Methods}

\subsection{Study area}

The current study was conducted in district Bannu Khyber Pakhtunkhwa province Pakistan. The district is located in the South of the province, covering $1227 \mathrm{Km}^{2}$ areas with a population of $1,167,892$ according to the 2017 consensus. It lies between $32^{\circ}-43$ and $33^{\circ}-06 \mathrm{~N}$ latitude and $73^{\circ}-20$ and $70^{\circ}-07 \mathrm{E}$ longitude (Pakistan, 1998).

\subsection{Samples collection}

A total of 180 stool specimens were collected from infants and children age less than five years, from January to December 2015, who were admitted to two main hospitals (District Head Quarter and Khalifa Gul Nawaz) diagnosed with AGE. The age range was one to 60 months. Stool specimens (each 5-10 mL) were collected in a sterile screw-capped plastic container under aseptic conditions with informed consent from their parents/guardians. Children with watery diarrhea, vomiting and nausea were included in the study. The criteria for AGE were defined as the existence of $\geq 3$ times watery or looser-than-normal stool samples per day and lasts for less than 14 days. The information recorded was the child's sex, age, address, disease symptoms, risk factors, hydration status, inpatients, and outpatients through the proper questionnaire. The seasonal and climatic conditions of the above-cited hospitals were the same because of their locality in the same district, though differences were observed in the management and hygienic condition of the areas. Ethical approval of the study plan was granted by the Research Ethical Committee of Kohat University of Science and Technology (KUST) Kohat, Khyber Pakhtunkhwa Pakistan. All samples were brought to the Virology Laboratory, Department of Zoology, KUST, and were stored at $-70{ }^{\circ} \mathrm{C}$ for further analysis.

\subsection{Stool sample dilution, preparation of $10 \%$ suspension, and RNA extraction}

The stool sample was initially diluted in phosphate buffer saline (PBS). Further, a stool sample (1g or 100 $\mu$ l) was taken in a labeled eppendorf tube and mixed with $900 \mu \mathrm{l}$ PBS. Vortexed for few seconds till suspension and then centrifuged at $14,000 \mathrm{rpm}$ for $15 \mathrm{~min}$. After centrifugation, 
the clear liquid at top of the lysate was collected by micropipette and stored at $-70^{\circ} \mathrm{C}$ until use. Further, RNA was isolated using Favorgen Nucleic acid extraction Kit (Viventus, Germany) according to manufacturer protocols, in a type II Biosafety cabinet.

\subsection{Detection of Rotavirus and their genotypes}

Initially, cDNA was synthesized with random hexamers using 200U/ul of moloneymureine leukemia virus reverse transcriptase (Fermentas USA). The thermal cycling was performed as follows: denaturation at $25^{\circ} \mathrm{C}$ for $10 \mathrm{~min}$, then at $42^{\circ} \mathrm{C}$ for $50 \mathrm{~min}$, and at $90{ }^{\circ} \mathrm{C}$ for $5 \mathrm{~min}$.

cDNA was subjected to Rotavirus $\mathrm{G}$-typing with consensus forward and reverse primers (Table-1) to amplify the VP7 gene using the protocol of Iturriza-Gómara et al., 2004; Simmonds et al., 2008. Briefly, a total of 25 ul reaction volume consisted of $2 \mu \mathrm{l}$ of extracted cDNA, $2 \mathrm{mM} \mathrm{MgCl}_{2}, 20 \mathrm{pM}$ of each VP7-F forward and reverse primer. The thermal cycling was performed as: Initial denaturation at $95^{\circ} \mathrm{C}$ for $3 \mathrm{~min}$, then 25 cycles of $95^{\circ} \mathrm{C}$ for $45 \mathrm{sec}, 52^{\circ} \mathrm{C}$ for $45 \mathrm{sec}$ and $72^{\circ} \mathrm{C}$ for $60 \mathrm{sec}$ and final extension was $72{ }^{\circ} \mathrm{C}$ for $10 \mathrm{~min}$.

\subsubsection{Semi nested type specific PCR (G-typing)}

The amplified product of the first round PCR was carried out in the next round of PCR meant for Rotavirus $\mathrm{G}$-genotypes. Each reaction consisted of $2.5 \mathrm{mM}$ of $\mathrm{MgCl}_{2}$, 20pM of a reverse primer (VP7-R) and seven forward primers (Table 1 ) were used for specific genotypes of Rotavirus. PCR program was as: Initial denaturation at $95{ }^{\circ} \mathrm{C}$ for $3 \mathrm{~min}$, then 30 cycles of $95^{\circ} \mathrm{C}$ for $45 \mathrm{sec}, 42^{\circ} \mathrm{C}$ for $45 \mathrm{sec}$ and $72{ }^{\circ} \mathrm{C}$ for $60 \mathrm{sec}$ and final extension was $72{ }^{\circ} \mathrm{C}$ for $10 \mathrm{~min}$.

\subsubsection{Regular PCR (P-typing)}

First strand cDNA was amplified with VP4 forward and reverse primers (each $20 \mathrm{mM}$ ) given in table-1 according to Iturriza-Gómara et al. (2004) and Simmonds et al. (2008). A single reaction was composed of $2.5 \mathrm{mM} \mathrm{MgCl}$, 20 pM of eachVP4-F and VP4-R primers. The thermal cycling was performed as follow: Initial denaturation was at $95^{\circ} \mathrm{C}$ for $3 \mathrm{~min}$, then 30 cycles of $95^{\circ} \mathrm{C}$ for $45 \mathrm{sec}$, $54{ }^{\circ} \mathrm{C}$ for $45 \mathrm{sec}$ and $72{ }^{\circ} \mathrm{C}$ for $60 \mathrm{sec}$ and final extension was at $72^{\circ} \mathrm{C}$ for $10 \mathrm{~min}$.

Table 1. Consensus Primers for G and P type and their Amplicon size.

\begin{tabular}{|c|c|c|}
\hline Primers & Sequences (5'-3') & Sizes (bp) \\
\hline \multicolumn{3}{|l|}{ Type G (a) } \\
\hline \multicolumn{3}{|l|}{ 1st round (Consensus) } \\
\hline VP7-F & ATGTATGGTATTGAATATACCAC & 881 \\
\hline VP7-R & AACTTGCCACCATTTTTTCC & \\
\hline \multicolumn{3}{|c|}{ Second round for type G-Specific } \\
\hline G1 & CAAGTACTCAAATCAATGATGG & 618 \\
\hline G 2 & CAATGATATTAACACATTTTCTGTG & 521 \\
\hline G 3 & ACGAACTCAACACGAGAGG & 682 \\
\hline G 4 & CGTTTCTGGTGAGGAGTTG & 452 \\
\hline G 8 & GTCACACCATTTGTAAATTCG & 754 \\
\hline G 9 & CTTGATGTGACTAYAAATAC & 179 \\
\hline G 10 & ATGTCAGACTACARATACTGG & 266 \\
\hline VP7-Reverse & AACTTGCCACCATTTTTTCC & \\
\hline \multicolumn{3}{|l|}{ Type-P } \\
\hline \multicolumn{3}{|l|}{ First Round for VP4 } \\
\hline VP4-F & TATGCTCCAGTNAATTGG & 663 \\
\hline VP4R & ATTGCATTTCTTTCCATAATG & \\
\hline \multicolumn{3}{|c|}{ Second Round for specific P-type } \\
\hline P-4 & CTATTGTTAGAGGTTAGAGTC & 362 \\
\hline P-6 & TGTTGATTAGTTGGATTCAA & 146 \\
\hline P-8 & TCTACTGGRTTRACNTGC & 224 \\
\hline P-9 & TGAGACATGCAATTGGAC & 270 \\
\hline $\mathrm{P}-10$ & ATCATAGTTAGTAGTCGG & 462 \\
\hline $\mathrm{P}-11$ & GTAAACATCCAGAATGTG & 191 \\
\hline VP4-Farward(b) & TATGCTCCAGTNAATTGG & \\
\hline
\end{tabular}




\subsubsection{Semi nested type specific PCR (P-typing)}

PCR product (for P-typing) was further amplified through 20pM of a reverse (VP4-F) and six P-typing forward primers. The thermal cycling was performed as follow: Initial denaturation was at $95^{\circ} \mathrm{C}$ for 3 min then 30 cycles of $95^{\circ} \mathrm{C}$ for $45 \mathrm{sec}, 45^{\circ} \mathrm{C}$ for $45 \mathrm{sec}$ and $72^{\circ} \mathrm{C}$ for $60 \mathrm{sec}$ and final extension was $72{ }^{\circ} \mathrm{C}$ for $10 \mathrm{~min}$.

\subsection{Gel electrophoresis}

The amplified product of semi-nested PCR was analyzed through $2 \%$ agarose gel. The specific cDNA products were determined by comparing them with the 100bp DNA ladder marker (Fermentas Germany) under UV transilluminator.

\subsection{Data analysis and organization}

Statistical analysis was performed using the statistical program SPSS version 16.0. Variation in proportions of Rotavirus (+) in gender-wise, various age groups, and urban via rural areas were tested using the chi-square test. A $P$-value less than 0.05 was considered statistically significant.

\section{Results}

\subsection{Age and gender-wise prevalence}

All children were infected with AGE of about 1-3 days before hospitalization. The study population was divided into three age groups (Months wise), to observe the association of child age and gender with the prevalence of Rotavirus infection. Group, I (0-20M) contain 156 children of which 36 (30 male and 6 female) were positive for Rotavirus. Among age group II (21-40M), out of total 20 children, 4 were positive ( 3 male) and ( 1 female). In age group III (41-60) out of total 4 male children, 1 was positive, and no female was detected in these age groups. Significantly highest Rotavirus infection was observed in male ( 34 positives; $\mathrm{p}<0.05$ ) than female children ( 7 positive; $\mathrm{p}>0.05$ ) (Table-2).

\subsection{Risk factors and clinical symptoms of Rotavirus in children}

Various risk factors and clinical symptoms associated with Rotavirus infected children were studied. The most frequent symptoms among the infected individuals were fever, AGE, abdominal pain, vomiting while risk factors were bottle feeding and immune compromised children were also observed. Therefore, the result of clinical symptoms was analyzed as fever (58.8\%), vomiting (51.7\%), abdominal pain (48.2\%), and acute diarrhea (64.2\%) (Figure 1).

\subsection{Seasonality of Rotavirus AGE}

Rotavirus infection was found throughout the year and this study showed a substantial increase in the prevalence of Rotavirus in the summer and winter seasons. Out of the total 80 samples, 19 (23.73\%) were reported (+) in summer seasons. In addition, in winter, autumn and spring out of a total 66, 14 and 20 samples, 15(23\%), 3(21.4\%) and 4 (20\%) were positive by RT-PCR. Significantly Rotavirus infection was higher in summer season(19 positive; $\mathrm{p}<0.05)$ than other three seasons (Table-2). Month wise Rotavirus infection was observed high significantly in June followed by October, and November (Figure 2).

\subsection{Impact of feeding on Rotavirus AGE outcome}

In this study, the effect of bottle feeding versus breastfeeding on the outcome of Rotavirus infection was studied in young children and infants. The result showed that the rate of AGE infection was higher in bottle feeding $30(61.2 \%)$ than breastfeeding 11 (62.5\%) out of 49 and 16 children. The highest Rotavirus infection in infants was observed significantly due to bottle feeding(30 positive; $\mathrm{p}<0.05)$. The results showed that bottle feeding is the main risk factor in infected children with Rotavirus AGE.

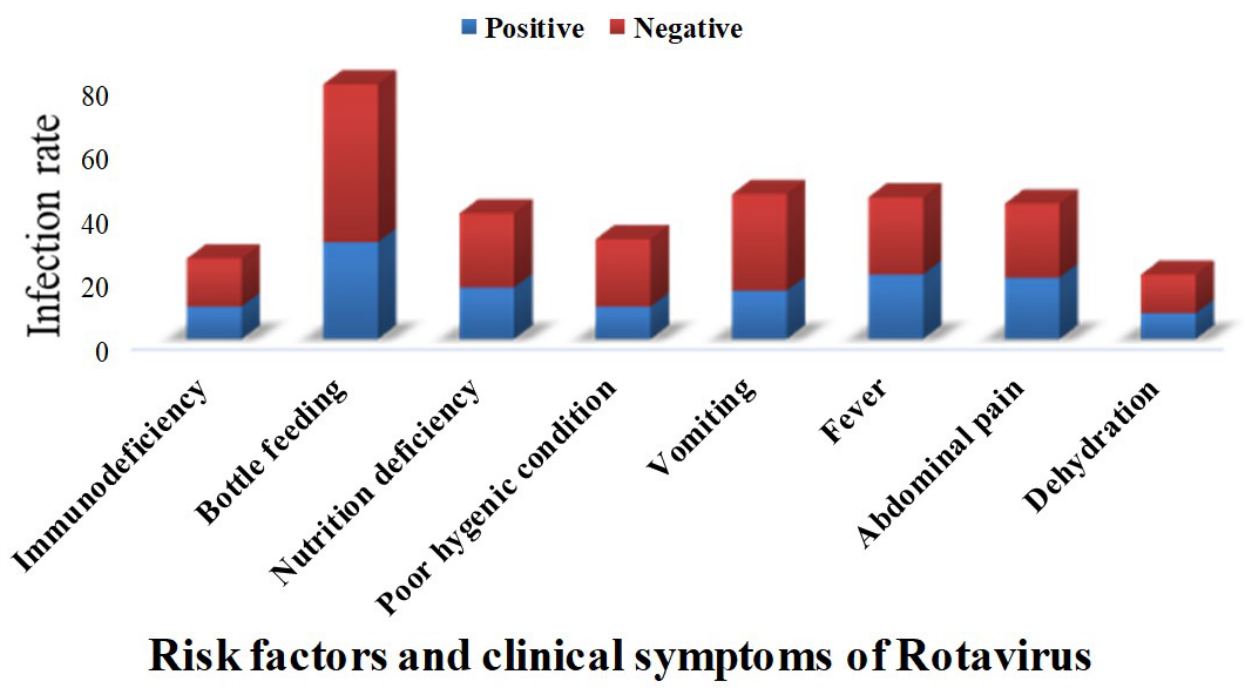

Figure 1. Risk factors and Clinical symptoms of Rotavirus. The Y-axis shows infection rate of Rotavirus and the X-axis shows risk factors and clinical symptoms. 


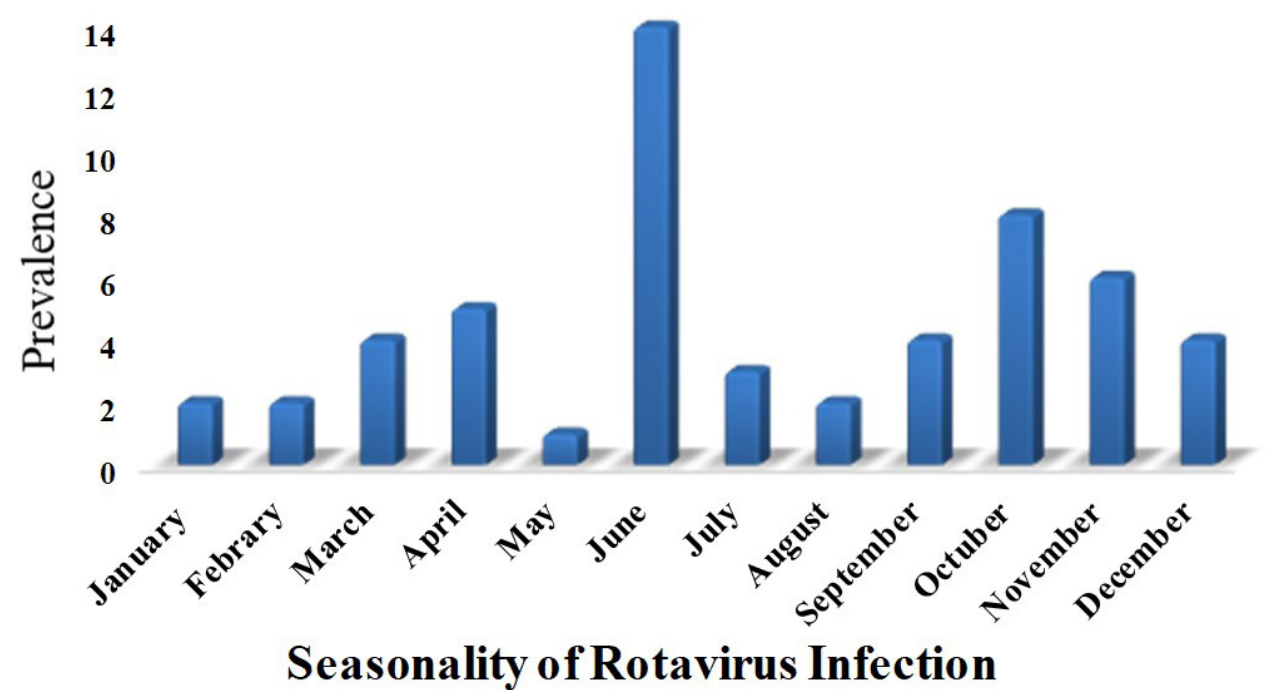

Figure 2. Seasonality of RV infection throughout the year. The Y-axis shows prevalence rate of Rotavirus infection and the X-axis shows month wise infection.

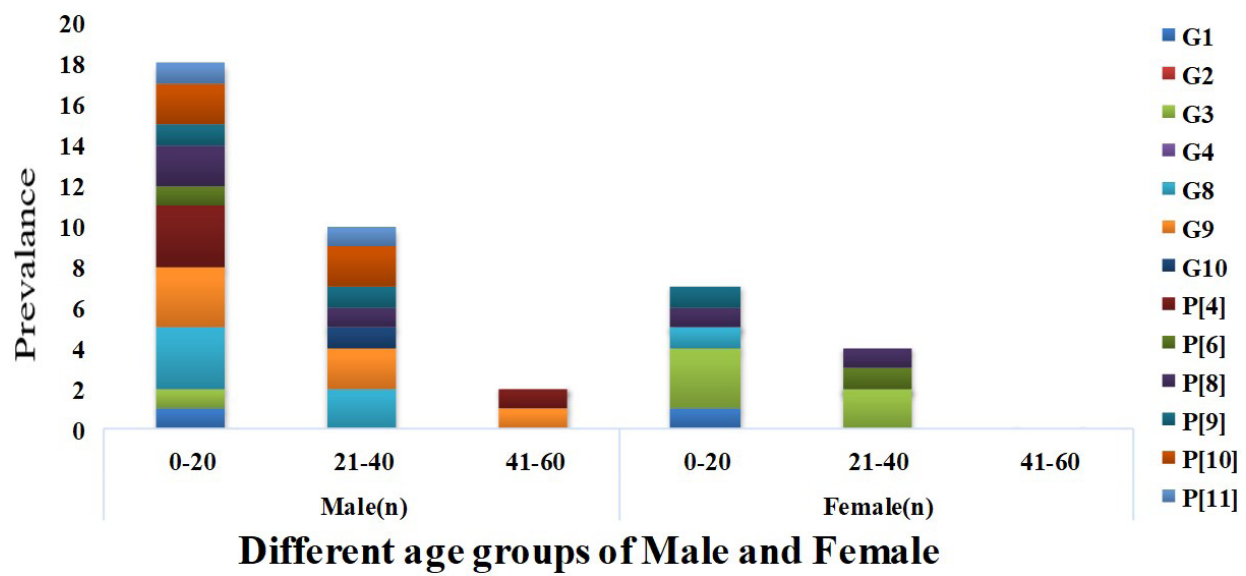

Figure 3. Correlation of various Genotypes with age groups. The Y-axis shows the number of prevalence genotypes and the X-axis shows gender wise individuals. Vertical bars with colors show different types of genotypes.

\subsection{Common genotype distribution by season, gender, and} age

In this study limitation of any genotype was not found in a specific Season, sex, age, and month. We also did not find any large variations in the ratio of $G$ and $P$ genotypes detected in various months. Three common genotypes G3, G8 and G9 were found throughout the year. The proportion of each age group was not similar almost. In the 1st age group, G8 and G9 each (3) were most prevalent. For instance, P-8 (5) followed by P-4 (4) and P-10 (4) was the most dominant genotype found in all age groups. All common genotypes were found in both male and female children with a different frequency. The proportion of G3, G8 and G9 was (1), (5), (6), while these values in female children were (5) and (1), G9 was not found in female children (Figure 3).

\subsection{Prevalence of Rotavirus genotypes}

Out of 180 samples, 21 were positive for G-type and 20 samples were positive for P-type. Both P and G type genotypes were identified. A total of 6 various $\mathrm{G}$-type and 5 different P-type were observed. Among the G-type G9 was the most frequently identified 6 (29\%) followed by G8 6(29\%), G3 6(29\%), G1 2(10\%) and G10 1(5\%). The predominant P genotype was P-85 (25\%) followed by P-4 4(20\%), P-10 4(20\%), P-9 3(15\%), P-6 and P-11 each 2(10\%) (Figure 4 \& 5).

\section{Discussion}

Rotavirus is the foremost cause of dreadful AGE in children under the age of five years. In Africa and, less developed countries of Asia, such as Pakistan, Vietnam, 


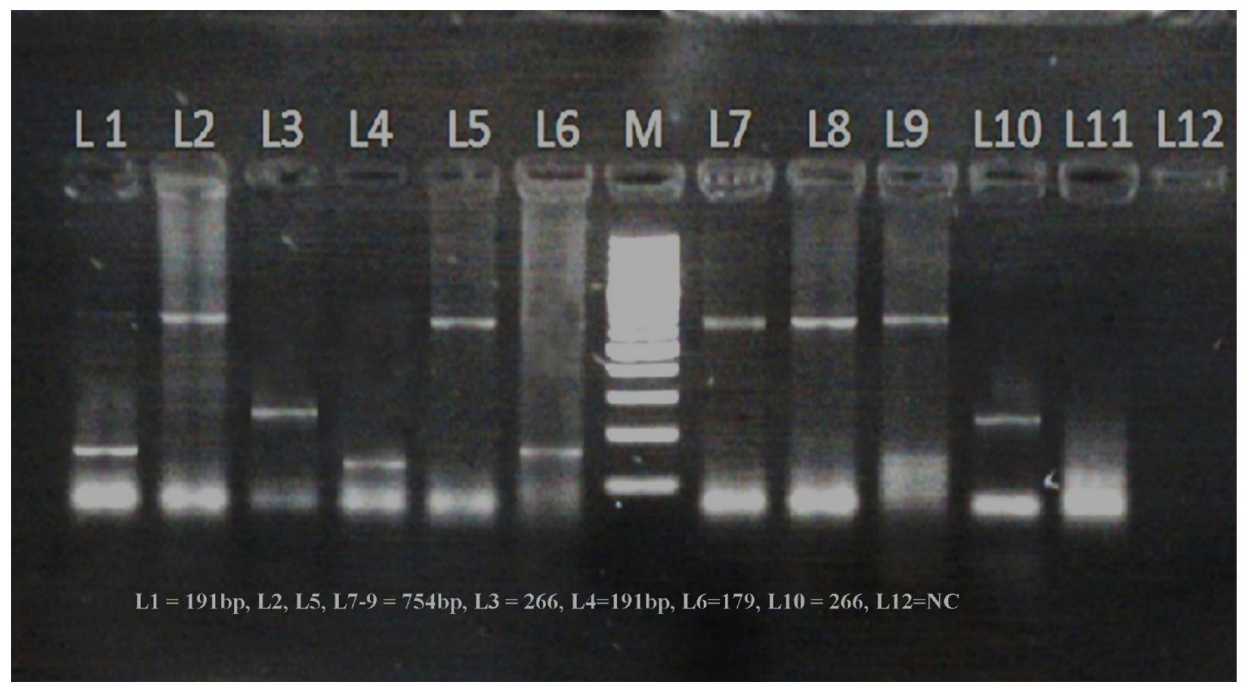

Figure 4. Detection of Various G-genotypes and one sample of P-type genotypes of Rotavirus through type-specific Primers. G-Genotype (M=Marker, L1=P-11, L2, L5, L7-9=G8 L3, L10=G10 =L4=P-11, L6=G9=Positive samples, L11, L12=Negative Samples).

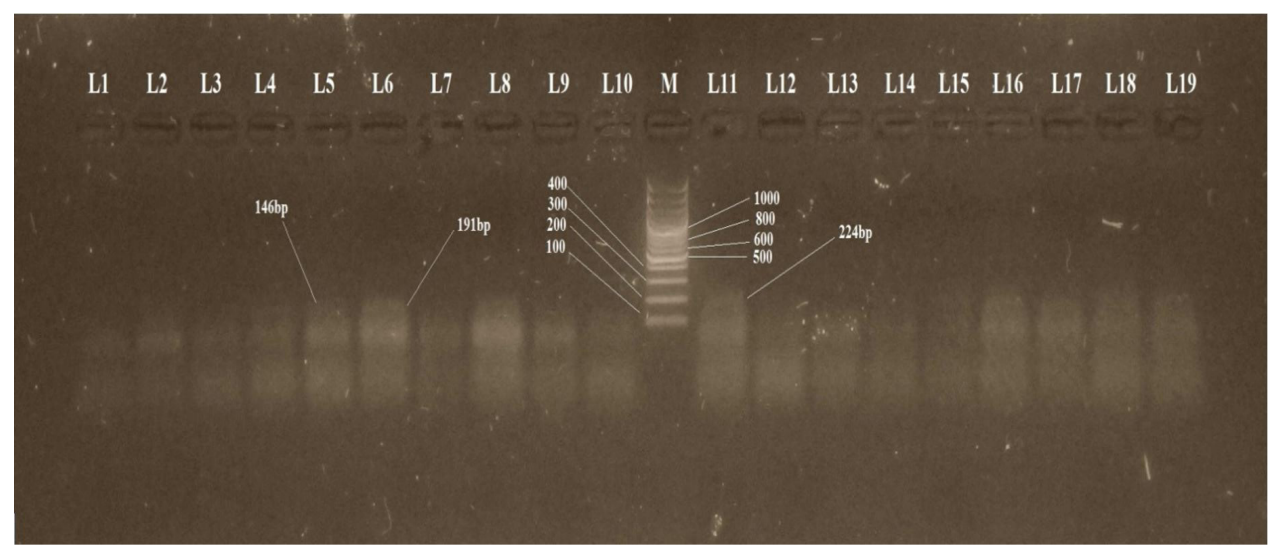

Figure 5. Detection of Various P genotype of Rotavirus through specific Primers. Type-specific PCR based detection of Rotavirus. P-Genotype (M=Marker, L5=P-6, L6=P-4, L11=P-8 =Positive samples, L1,L2,L3,L4,L7,L8, and L15= Negative Samples).

Bangladesh, India, and China, a high incidence of Rotavirus (30-40\%) has been recorded in admitted children (Armah et al., 2010). This study showed that it was the usual cause of diarrhea (23\%) in children of less than 5 years admitted to hospitals of district Bannu. The less percentage of the reported cases in our study may be due to the difference in the population of the sample sites.

In both low-income and developed countries, the viral infection is the most important root of AGE, particularly in Rotaviruses (Kazi et al., 2014). The 3 identified common groups of Rotavirus to cause infection mostly diarrhea in children are A, B \& C. Different P and G genotypes have been reported from various parts of the world (Macedo et al., 2007). This study focused on the clinical manifestation, molecular detection, and prevalence of different types of Rotavirus genotypes. The study showed infants and young children with severe infections such as AGE, Immunocompromised, continuously vomiting, abdominal pain, and fever (Figure 1). There was a difference in infection rate between the bottle feeding and breast-feeding children, via rural and urban areas. The result showed that the rate of AGE infection was higher in bottle feeding than breastfeeding children shown in (Table 2). Severe acute watery diarrhea was found mostly in unhygienic conditions such as limited clean water access and AGE infection recorded in less than 12 months of children. Mostly, hospitalized children with Rotavirus infection were recorded with malnutrition. The same trend and findings were found previously in another area of Pakistan with a difference that Rotavirus negative AGE commonly presented with vomiting, fever and had a little longer period compared to Rotavirus positive diarrhea patients. Rotavirus infection was detected by RT-PCR based on ages. Our results are in line with other studies showing the highest incidence of Rotavirus infection in children of less than one year (Logan et al., 2006). In our study, Rotavirus was detected highly in males than in females (children) because males excreted large amounts of Rotavirus in 
Table 2. Molecular detection of Rotavirus through PCR with respect to different variables.

\begin{tabular}{|c|c|c|c|c|c|}
\hline Variables & Positive & $\%$ age & Negative & $\%$ age & Total (\%) \\
\hline \multicolumn{6}{|l|}{ Sex } \\
\hline Male & 34 & $23.29^{*}$ & 112 & $76.7^{* *}$ & 146 \\
\hline Female & 7 & $20.59^{* *}$ & 27 & $79.4^{* *}$ & 34 \\
\hline Total & 41 & 23 & 139 & 77.2 & 180 \\
\hline \multicolumn{6}{|l|}{ Age (Months) } \\
\hline $0-20$ & 36 & $23^{*}$ & 120 & $76.9^{* *}$ & 156 \\
\hline $21-40$ & 4 & $20^{* *}$ & 16 & $80.0^{* *}$ & 20 \\
\hline $41-60$ & 1 & $25^{* *}$ & 3 & $75.0^{* *}$ & 4 \\
\hline Total & 41 & 22.78 & 139 & 77.2 & 180 \\
\hline \multicolumn{6}{|l|}{ Season wise } \\
\hline Summer & 19 & $23.75^{*}$ & 61 & $76.3^{* *}$ & 80 \\
\hline Winter & 15 & $23^{*}$ & 51 & $77.3^{* *}$ & 66 \\
\hline Autumn & 3 & $21.43^{* *}$ & 11 & $78.6^{* *}$ & 14 \\
\hline Spring & 4 & $20.00^{* *}$ & 16 & $80.0^{* *}$ & 20 \\
\hline Total & 41 & 22.78 & 139 & 77.2 & 180 \\
\hline \multicolumn{6}{|l|}{ Areas } \\
\hline Rural areas & 37 & $23.72^{*}$ & 119 & $76.3^{*}$ & 156 \\
\hline Urban areas & 4 & $16.67^{* *}$ & 20 & $83.3^{* *}$ & 24 \\
\hline Total & 41 & 23.29 & 139 & 76.7 & 180 \\
\hline \multicolumn{6}{|l|}{ Hospitalization } \\
\hline Inpatients & 32 & $22.22^{*}$ & 112 & $77.8^{*}$ & 144 \\
\hline Outpatients & 9 & $25.00^{* *}$ & 27 & $75.0^{* *}$ & 36 \\
\hline Total & 41 & 22.78 & 139 & 77.2 & 180 \\
\hline
\end{tabular}

Chai square test. ${ }^{*}$ Significant $(\mathrm{p}<0.05) .{ }^{* *}$ Nonsignificant $(\mathrm{p}>0.05)$.

their feces than females' children (Al-Khasra et al., 2002). Although studies from Yamen (Al-Badani et al., 2014) and Iran (Kazemi et al., 2006), are agreed upon significantly higher infection rates in children of less than one-year-old males. The rate of infection in our study in male to female children was (1.8: 1 ), which was in line with the reported ratios of 1.5: 1 from Bahrain and in anti-parallel to 1: 2.4 from India (Kahn et al., 2012). This result may be due to the vulnerability of males that probably to be admitted to hospitals than female children. This distinction sex susceptibility is uncertain and needs further investigation, while the reasons in various geographical location for the distinction in rate occurrence is also not understood (Armah et al., 2010). Additionally, the current study reported maximum infection of Rotavirus AGE in June, October and November which was parallel with a study done in Jordan (Nimri and Hijazi, 1996). However, Rotavirus infection was also reported in the cold, dry season in Tunisia (Hassine-Zaafrane et al., 2011), Morocco (Benhafid et al., 2013), and Nigeria (Junaid et al., 2011), which indicates epidemiological seasonal wise occurrence. Studies showed that Rotavirus infection was found throughout the year and a substantial increase in the positivity of infection in the summer and winter seasons.
Studies reported more than $85 \%$ Rotavirus genotypes, mostly five G-type (G9, G4, G3, G1) and three P- types P-8, P-6, P-4 circulating the world (Matthijnssens et al., 2011). The current study reported $100 \%$ of $G$ and $P$ genotypes of Rotavirus strains, where 3 genotypes were found common more than $30 \%$ as G9, G8 and G3. The most common G-types show variations in various geographical locations throughout the year (Da Silva Soares et al., 2014). For example, G1 was the most dominant genotype and show more than 70 percent of infection in Europe, Australia, North America, while during 1989 and 2004 its ratio was minimum than 30\% in Asia, Africa, and South America (Gentsch et al., 2005). In Tanzania, the dominant genotype was G1 followed by G12, G4, and G8 (Moyo et al., 2014). While in our study most predominant G9, G8 followed by G3 and G10 genotype. This result also showed a rise in the incidence of G9 and G8 strain of Rotavirus. In this study strains of Untypable were also composed an important part of the specimen, implying the existence of novel strains developing due to mutations that could not be detected with the primers used. Progress in genetic sequencing and improvement of the latest primers will facilitate the recognition of these new strains of Rotavirus and reduce the ratio of Untypable strains in the future. Though vaccines 
of Rotavirus have display cross safety against other strains, changes, and natural variability in strains of Rotavirus following the introduction of the Rotavirus vaccines dire need to be measured when evaluating the impact of existing vaccines and the development of new vaccines (Zaman et al., 2010). The prevalence proportion of each age group was not similar as in the 1st group of age, G8 and G9 were most prevalent. Whereas, in P-type genotypes $\mathrm{P}-8$ and $\mathrm{P}-4$ were mostly found in all age groups throughout the year. All common genotypes were found in both male and female children with a different frequency. Whereas the most prevalent $\mathrm{P}$ genotypes were $\mathrm{P}-4$ and $\mathrm{P}-8$ around the world. In our study, P-8 was reported in $25 \%$ followed by $\mathrm{P}-4, \mathrm{P}-10, \mathrm{P}-11$ (Figure $4 \& 5$ ) which is according to a study reported $\mathrm{P}-8$ in $46.8 \%$ followed by $\mathrm{P}-4$, of Rotavirus positive individuals from China (Sai et al., 2013).

\section{Conclusion}

The present study showed that Rotavirus is the foremost root of AGE in children and infants in district Bannu. Rotavirus infection was found throughout the year but most prevalent in the summer and winter seasons. Rotavirus is more prevalent in rural areas particularly in children aged less than 20 months.

\section{Acknowledgments}

Authors wish to thanks Research Supporting Project Number (RSP-2021/346), King Saud University Riyadh Saudi Arabia for their financial support.

\section{References}

ALAM, M.M., KHURSHID, A., SHAUKAT, S., SULEMAN, R.M., SHARIF, S., ANGEZ, M., MALIK, S.A., AHMED, T.M., AAMIR, U.B., NAEEM, M. and ZAIDI, S.S.Z., 2013. Epidemiology and genetic diversity of rotavirus strains in children with acute gastroenteritis in Lahore, Pakistan. PLoS One, vol. 8, no. 6, pp. e67998. http:// dx.doi.org/10.1371/journal.pone.0067998. PMid:23825693.

AL-BADANI, A., AL-AREQI, L., MAJILY, A., AL-SALLAMI, S., ALMADHAGI, A. and AMOOD AL-KAMARANY, M., 2014. Rotavirus diarrhea among children in Taiz, Yemen: prevalence risk factors and detection of genotypes. International Journal of Pediatrics, vol. 2014, pp. 928529. http://dx.doi.org/10.1155/2014/928529. PMid:25197286.

AL-KHASRA, K.R., NASHER, M.A. and JABBER, A.A., 2002. The detection of rotavirus among infants and young children suffering from diarrhea in Sana'a. Yemen Medical Journal, vol. 4, no. 1, pp. 60-63.

ARMAH, G.E., SOW, S.O., BREIMAN, R.F., DALLAS, M.J., TAPIA, M.D., FEIKIN, D.R., BINKA, F.N., STEELE, A.D., LASERSON, K.F., ANSAH, N.A., LEVINE, M.M., LEWIS, K., COIA, M.L., ATTAH-POKU, M., OJWANDO, J., RIVERS, S.B., VICTOR, J.C., NYAMBANE, G., HODGSON, A., SCHÖDEL, F., CIARLET, M. and NEUZIL, K.M., 2010. Efficacy of pentavalent rotavirus vaccine against severe rotavirus gastroenteritis in infants in developing countries in sub-Saharan Africa: a randomized, double-blind, placebocontrolled trial. Lancet, vol. 376, no. 9741, pp. 606-614. http:// dx.doi.org/10.1016/S0140-6736(10)60889-6. PMid:20692030.
BENHAFID, M., ELOMARI, N., ELQAZOUI, M., MERYEM, A.I., RGUIG, A., FILALI-MALTOUF, A. and ELAOUAD, R., 2013. Diversity of rotavirus strains circulating in children under 5 years of age admitted to hospital for acute gastroenteritis in Morocco, June 2006 to May 2009. Journal of Medical Virology, vol. 85, no. 2, pp. 354-362. http://dx.doi.org/10.1002/jmv.23445. PMid:23074038.

GENTSCH, J.R., LAIRD, A.R., BIELFELT, B., GRIFFIN, D.D., BÁNYAI, K., RAMACHANDRAN, M., JAIN, V., CUNLIFFE, N.A., NAKAGOMI, O., KIRKWOOD, C.D., FISCHER, T.K., PARASHAR, U.D., BRESEE, J.S., JIANG, B. and GLASS, R.I., 2005. Serotype diversity and reassortment between human and animal rotavirus strains: implications for rotavirus vaccine programs. The Journal of Infectious Diseases, vol. 192, suppl. 1, pp. S146-S159. http:// dx.doi.org/10.1086/431499. PMid:16088798.

HABIB, M.I., KAZI, S.G., KHAN, K.M.A. and ZIA, N., 2014. Rotavirus diarrhea in hospitalized children. Journal of the College of Physicians and Surgeons, vol. 24, no. 2, pp. 114-117. PMid:24491006.

HASSINE-ZAAFRANE, M., SDIRI-LOULIZI, K., SALEM, I.B., KAPLON, J., AYOUNI, S., AMBERT-BALAY, K., SAKLY, N., POTHIER, P. and AOUNI, M., 2011. The molecular epidemiology of circulating rotaviruses: three-year surveillance in the region of Monastir, Tunisia. BMC Infectious Diseases, vol. 11, no. 1, pp. 266. http:// dx.doi.org/10.1186/1471-2334-11-266. PMid:21967503.

IFTIKHAR, T., BUTT, A., NAWAZ, K., SARWAR, Y., ALI, A., MUSTAFA, T. and HAQUE, A., 2012. Genotyping of Rotaviruses detected in children admitted to hospital from Faisalabad Region, Pakistan. Journal of Medical Virology, vol. 84, no. 12, pp. 2003-2007. http:// dx.doi.org/10.1002/jmv.23402. PMid:23080509.

ITURRIZA-GÓMARA, M., KANG, G. and GRAY, J., 2004. Rotavirus genotyping: keeping up with an evolving population of human rotaviruses. Journal of Clinical Virology, vol. 31, no. 4, pp. 259-265. http://dx.doi.org/10.1016/j.jcv.2004.04.009. PMid:15494266.

JUNAID, S.A., UMEH, C., OLABODE, A.O. and BANDA, J.M., 2011. Incidence of rotavirus infection in children with gastroenteritis attending Jos university teaching hospital, Nigeria. Virology Journal, vol. 8, no. 1, pp. 233. http://dx.doi.org/10.1186/1743422X-8-233. PMid:21575246.

KAHN, G., FITZWATER, S., TATE, J., KANG, G., GANGULY, N., NAIR, G., STEELE, D., ARORA, R., CHAWLASARKAR, M., PARASHAR, U. and SANTOSHAM, M., 2012. Epidemiology and prospects for prevention of Rotavirus disease in India. Indian Pediatrics, vol. 49, no. 6, pp. 467-474. http://dx.doi.org/10.1007/s13312-0120076-7. PMid:22796685.

KAWAI, K., O'BRIEN, M.A., GOVEIA, M.G., MAST, T.C. and EL KHOURY, A.C., 2012. Burden of rotavirus gastroenteritis and distribution of rotavirus strains in Asia: a systematic review. Vaccine, vol. 30, no. 7, pp. 1244-1254. http://dx.doi.org/10.1016/j. vaccine.2011.12.092. PMid:22212128.

KAZEMI, A., TABATABAIE, F., AGHA-GHAZVINI, M.R. and KELISHADI, R., 2006. The role of Rotavirus in acute pediatric diarrhea in Isfahan, Iran. Pakistan Journal of Medical Sciences, vol. 22, no. 3, pp. 282-285.

KAZI, A.M., WARRAICH, G.J., QURESHI, S., QURESHI, H., KHAN, M.M.A. and ZAIDI, A.K.M., 2014. Sentinel hospital-based surveillance for assessment of burden of rotavirus gastroenteritis in children in Pakistan. PLoS One, vol. 9, no. 10, pp. e108221. http://dx.doi. org/10.1371/journal.pone.0108221. PMid:25295613.

KILGORE, A., DONAUER, S., EDWARDS, K.M., WEINBERG, G.A., PAYNE, D.C., SZILAGYI, P.G., RICE, M., CASSEDY, A., ORTEGASANCHEZ, I.R., PARASHAR, U.D. and STAAT, M.A., 2013. Rotavirusassociated hospitalization and emergency department costs and rotavirus vaccine program impact. Vaccine, vol. 31, no. 38, 
pp. 4164-4171. http://dx.doi.org/10.1016/j.vaccine.2013.06.085. PMid:23845802.

LOGAN, C., O'LEARY,J.J. and O'SULLIVAN, N., 2006. Real-time reverse transcription-PCR for detection of rotavirus and adenovirus as causative agents of acute viral gastroenteritis in children. Journal of Clinical Microbiology, vol. 44, no. 9, pp. 3189-3195. http://dx.doi.org/10.1128/JCM.00915-06. PMid:16954246.

MACEDO, C.I., CHRISTOFOLETTI, A., MUNFORD, V. and RÁCZ, M.L., 2007. $G$ and P rotavirus genotypes in stool samples from children in Teresina, State of Piauí. Revista da Sociedade Brasileira de Medicina Tropical, vol. 40, no. 4, pp. 381-384. http://dx.doi. org/10.1590/S0037-86822007000400001. PMid:17876455.

MARTELLA, V., BÁNYAI, K., MATTHIJNSSENS, J., BUONAVOGLIA, C. and CIARLET, M., 2010. Zoonotic aspects of rotaviruses. Veterinary Microbiology, vol. 140, no. 3-4, pp. 246-255. http:// dx.doi.org/10.1016/j.vetmic.2009.08.028. PMid:19781872.

MARTINEZ-GUTIERREZ, M., ARCILA-QUICENO, V., TREJOS-SUAREZ, J. and RUIZ-SAENZ, J., 2019. Prevalence and molecular typing of rotavirus in children with acute diarrhea in Northeastern Colombia. Revista do Instituto de Medicina Tropical de São Paulo, vol. 61, pp. e34. http://dx.doi.org/10.1590/s1678-9946201961034. PMid:31269110.

MATTHIJNSSENS, J., CIARLET, M., MCDONALD, S.M., ATTOUI, H., BÁNYAI, K., BRISTER, J.R., BUESA, J., ESONA, M.D., ESTES, M.K., GENTSCH, J.R., ITURRIZA-GÓMARA, M., JOHNE, R., KIRKWOOD, C.D., MARTELLA, V., MERTENS, P.P., NAKAGOMI, O., PARREÑO, V., RAHMAN, M., RUGGERI, F.M., SAIF, L.J., SANTOS, N., STEYER, A., TANIGUCHI, K., PATTON, J.T., DESSELBERGER, U. and VAN RANST, M., 2011. Uniformity of rotavirus strain nomenclature proposed by the Rotavirus Classification Working Group (RCWG) Archives of Virology, vol. 156, no. 8, pp. 1397-1413. http://dx.doi. org/10.1007/s00705-011-1006-z. PMid:21597953.

MATTHIJNSSENS, J., CIARLET, M., RAHMAN, M., ATTOUI, H., BÁNYAI, K., ESTES, M.K., GENTSCH, J.R., ITURRIZA-GÓMARA, M., KIRKWOOD, C.D., MARTELLA, V., MERTENS, P.P., NAKAGOMI, O., PATTON, J.T., RUGGERI, F.M., SAIF, L.J., SANTOS, N., STEYER, A., TANIGUCHI, K., DESSELBERGER, U. and VAN RANST, M., 2008. Recommendations for the classification of group A rotaviruses using all 11 genomic RNA segments. Archives of Virology, vol. 153, no. 8, pp. 1621-1629. http://dx.doi.org/10.1007/s00705008-0155-1. PMid:18604469.

MOYO, S.J., BLOMBERG, B., HANEVIK, K., KOMMEDAL, O., VAINIO, K., MASELLE, S.Y. and LANGELAND, N., 2014. Genetic diversity of circulating rotavirus strains in Tanzania prior to the introduction of vaccination. PLoS One, vol. 9, no. 5, pp. e97562. http://dx.doi. org/10.1371/journal.pone.0097562. PMid:24844631.

NIMRI, L.F. and HIJAZI, S.A., 1996. Rotavirus-associated diarrhea in children in a refugee camp in Jordan. Journal of Diarrhoeal Diseases Research, vol. 14, no. 1, pp. 1-4. PMid:8708326.
PAKISTAN, 1998. District census report of Bannu. Population census organization. Islamabade: Statistic Division, Government of Pakistan.

PHAN, T.G., KHAMRIN, P., QUANG, T.D., DEY, S.K., TAKANASHI, S., OKITSU, S., MANEEKARN, N. and USHIJIMA, H., 2007. Detection and genetic characterization of group A Rotavirus strains circulating among children with acute gastroenteritis in Japan. Journal of Virology, vol. 81, no. 9, pp. 4645-4653. http://dx.doi. org/10.1128/JVI.02342-06. PMid:17301134.

QAZI, R., SULTANA, S., SUNDAR, S., WARRAICH, H., UN-NISA, T., RAIS, A. and ZAIDI, A.K.M., 2009. Population-based surveillance for severe Rotavirus gastroenteritis in children in Karachi, Pakistan. Vaccine, vol. 27, suppl. 5, pp. F25-30. http://dx.doi.org/10.1016/j. vaccine.2009.08.064. PMid:19931714.

SADIQ, A., BOSTAN, N., BOKHARI, H., MATTHIJNSSENS, J., YINDA, K.C., RAZA, S. and NAWAZ, T., 2019. Molecular characterization of human group A Rotavirus genotypes circulating in Rawalpindi, Islamabad, Pakistan during 2015-2016. PLoS One, vol. 14, no. 7, pp. e0220387. http://dx.doi.org/10.1371/journal.pone.0220387. PMid:31361761.

SAI, L., SUN, J., SHAO, L., CHEN, S., LIU, H. and MA, L., 2013. Epidemiology and clinical features of Rotavirus and norovirus infection among children in Jinan, China. Virology Journal, vol. 10, no. 1, pp. 302. http://dx.doi.org/10.1186/1743-422X-10-302. PMid:24099150.

SIMMONDS, M.K., ARMAH, G., ASMAH, R., BANERJEE, I., DAMANKA, S., ESONA, M., GENTSCH, J.R., GRAY, J.J., KIRKWOOD, C., PAGE, N. and ITURRIZA-GÓMARA, M., 2008. New oligonucleotide primers for P-typing of Rotavirus strains: strategies for typing previously untypeable strains. Journal of Clinical Virology, vol. 42, no. 4, pp. 368373. http://dx.doi.org/10.1016/j.jcv.2008.02.011. PMid:18378188.

SOARES, L.S., GUERRA, S.F.S., OLIVEIRA, A.S.L., SANTOS, F.S., MENEZES, E.M.F.C, MASCARENHAS, J.D.A.P. and LINHARES, A.C., 2014. Diversity of Rotavirus strains circulating in Northern Brazil after introduction of a Rotavirus vaccine: high prevalence of G3P [6] genotype. Journal of Medical Virology, vol. 86, no. 6, pp. 10651072. http://dx.doi.org/10.1002/jmv.23797. PMid:24136444.

TATE, J.E., BURTON, A.H., BOSCHI-PINTO, C., PARASHAR, U.D., AGOCS, M., SERHAN, F., DE OLIVEIRA, L., MWENDA, J.M., MIHIGO, R. and WIJESINGHE, P.R., 2016. Global, regional, and national estimates of Rotavirus mortality in children< 5 years of age, 2000-2013. Clinical Infectious Diseases, vol. 62, suppl. 2, pp. S96-S105. http:// dx.doi.org/10.1093/cid/civ1013. PMid:27059362.

ZAMAN, K., DANG, D.A., VICTOR, J.C., SHIN, S., YUNUS, M., DALLAS, M.J., PODDER, G., VU, D.T., LE, T.P., LUBY, S.P., LE, H.T., COIA, M.L., LEWIS, K., RIVERS, S.B., SACK, D.A., SCHÖDEL, F., STEELE, A.D., NEUZIL, K.M. and CIARLET, M., 2010. Efficacy of pentavalent rotavirus vaccine against severe Rotavirus gastroenteritis in infants in developing countries in Asia: a randomised, double-blind, placebo-controlled trial. Lancet, vol. 376, no. 9741, pp. 615-623. http://dx.doi.org/10.1016/S0140-6736(10)60755-6. PMid:20692031. 